\title{
Dijital Sağlık Hizmetlerinin Sürdürülebilir Kalkınma Hedefleri Açısından Değerlendirilmesi
}

DOI: $10.26466 /$ opus.927187

*

\author{
Hilal Özen* \\ * Doç. Dr., Trakya Üniversitesi , İktisadi İdari Bilimler Fakültesi, Edirne/Türkiye \\ E-Posta: hilalozen@trakya.edu.tr \\ ORCID: $\underline{0000-0002-2566-5098}$
}

\begin{abstract}
Öz
Günümüzde COVID-19 salgının da etkisiyle hızla gelişen dijital sağlık hizmetleri giderek önem kazanırken, bireylerin sağlık çalışanlarına yer ve zamandan bağımsız olarak daha hızlı ve kolay ulaşmasına imkânı vermektedir. Sağlık çalışanlar ile online ortamda yüz yüze görüşmeler gerçekleştirilmesine de olanak veren tele tıp ve mobil sağlık uygulamaları bireylerin sağllk hizmetlerine erişimini kolaylaştırmaktadır. Eylül 2015'te Birleşmiş Milletler tarafindan gerçekleştirilen Sürdürülebilir Kalkınma Zirvesi'nde 193 üye devlet tarafindan 17 adet Sürdürülebilir Kalkınma Hedefi belirlenmiştir. Bu hedeflerin pek çok alanda olduğu gibi sağglk alanında da etkileri bulunmaktadır. BM Sürdürülebilir Kalkınma Hedefleri Zirvesi'ne katılan üye devletlerin sağllkla ilgili Sürdürülebilir Kalkınma Hedeflerinde ilerlemeyi hızlandırmak için bilgi ve iletişim teknolojilerinin potansiyelinden yararlanmayı taahhüt etmelerinden ilham alarak gerçekleştirilen bu çalışma, dünyada ve ülkemizde giderek çok daha ivmeli bir şekilde büyüyen dijital sağlık hizmetleri pazarma dikkatleri çekmek ve bu hizmetleri Birleşmiş Milletler'in Sürdürülebilir Kalkınma Hedefleri kapsammnda değerlendirmek üzere hazırlanmıştır. Bu çalışmanın amacı dijital sağlık uygulamaları kapsamında olan ayn zamanda Türkiye'de de yaygınlaşmaya başlayan tele tıp ve mobil sağlık hizmetlerinin, BM'nin Sürdürülebilir Kalkımma Hedefleri 'ne olan etki ve katkılarmı incelemektir. Bu bağlamda, belirtilen sağlık uygulamalarmın Sürdürülebilir Kalkınma Hedeflerinden Hedef 3'e doğrudan, Hedef 10 ile Hedef 13'e ise dolaylı etkileri bulunduğu sonucuna varılmıştır.
\end{abstract}

Anahtar Kelimeler: COVID-19, dijital sağlık, tele tıp, mobil sağllk, sürdürülebilir kalkınma hedefleri. 


\title{
Evaluation of Digital Health Services in Terms of Sustainable Development Goals
}

\begin{abstract}
Digital health services which are developing rapidly with the effect of the COVID-19 pandemic give individuals faster and easier access to healthcare professionals, regardless of place and time. Telemedicine and mobile health applications, which also allow face-to-face online interviews with healthcare professionals, facilitate individuals' access to healthcare services. In September 2015, 193 member states determined 17 Sustainable Development Goals (SDG) at "Sustainable Development Summit" held by United Nations. These goals have effects in the field of health as well as in many other areas. This study, inspired by the commitment of the member states participating in the UN Sustainable Development Summit to take advantage of the potential of information and communication technologies for accelerating the progress in health-related Sustainable Development Goals. For this reason, this study draws attention to the increasingly growing digital health services market in Turkey as well as in the world and has been prepared to evaluate these services within the scope of Sustainable Development Goals. The aim of this study, is to examine the impact and contribution of telemedicine and mobile health services, that are also spreading in Turkey, on sustainable development goals. In this context, it has been concluded that the specified health practices have direct effects on SDG 3, and indirect effects on SDG 10 and SDG 13.
\end{abstract}

Keywords: COVID-19, digital health, telemedicine, mobile health, sustainable development goals. 


\section{Giriş}

Günümüzde gelişen teknoloji, değişen tüketici davranışları ve talepleriyle de birlikte pek çok sektörde köklü değişimler yaşandığını, hatta bazı sektörler tamamen ortadan kalkarken, daha önce hiç bilmediğimiz duymadığımız yeni sektörlerin de ortaya çıktı̆̆ını görmekteyiz. Bu manada dijital teknolojiler gelişim ve değişimde öncü rol üstlenmektedir. Dijital teknolojiler pek çok alanda daha fazla benimsenirken sağlık alanında da bu teknolojilerin gelişimi yükselmekte, sağlık hizmetlerine olan erişim kolaylaşmaktadır. Dijital teknolojiler sağlık hizmetlerinde de köklü bir değişiklik yaşanmasına sebep olmaktadır. Özellikle 2020'nin ilk çeyreğinden bu yana girmiş olduğumuz COVID-19 salgını süreci tüm dünyayı hiç beklenmedik bir şekilde etkilerken, sağlık alanında dijitalleşmede de beklenenin çok üzerinde gelişmeler yaşanmasına sebep oldu. Daha önce hiç karşılaşmadığımız, belki de karşılaşsak da kullanmayı düşünmediğimiz pek çok dijital sağlık hizmeti hayatımıza girmeye başlamıştır.

Özellikle bu salgın süreci içerisinde pek çok kişinin COVID-19'dan korunmak için, daha önceden planlanmış bile olsa yüz yüze muayene hizmetlerinden kaçınmaya başlaması COVID-19 haricinde de farklı sağlık problemleri yaşama ihtimalinin de artmasına sebep oldu. Bu durum da sağlıkta dijitalleşmenin önemini bir kez daha ortaya koymuş oldu. Dolayısıyla bir ülkede devlet hastaneleri, üniversiteler ya da özel hastanelerin dijital sağlık hizmeti sunma olanakları var ise topluma, aynı zamanda sağlık çalışanlarına, onları hastalığın yayılmasından koruyacakları için fayda sağlayacağı muhakkaktır. Bu faydasının yanısıra insanların evden çıkamama gibi durumları, özellikle de karantina ortamında dijital sağlık hizmetlerinin önemini daha öne çıkmaktadır. Bu hem hasta hem de doktor açısından avantajlı bir durumdur. Çünkü, sağlık çalışanları da bu hastalıktan muzdarip olarak dışarı çıkamadıkları zamanlarda acil görüşme ihtiyacı olan hastalarına bu sayede kolayca ulaşma imkânı bulmaktadırlar.

$\mathrm{Bu}$ hizmetler sayesinde hastaneleri ziyaret eden hasta sayılarında azalma da olabilirken, sağlık çalışanlarının iş yükünde de azalma yaşanması mümkündür. Türkiye'de COVID-19 salgını sırasında bazı özel hastaneler, diyetisyenler, psikologlar, dermatologlar, diş hekimleri gibi sağlık çalışanları web sayfaları, mobil aplikasyonlar, sosyal medya he- 
sapları, SMS (kısa mesaj hizmetleri) ve e-posta yoluyla dijital sağlık hizmeti sunmaya başladılar. Ancak, ülkemizde toplumun önemli bir kısmının sağlık hizmetlerini devlet hastaneleri ya da sağlık ocaklarından aldıkları düşünülürse aslında henüz istenilen düzeylere ulaşılabildiğini söylemek çok da mümkün olmuyor.

Dijital sağlık hizmetlerinin hastalar ve de sağlık çalışanları açısından faydalarından bahsetmek elbette mümkün, ancak bu hizmetlerin aynı zamanda sürdürülebilirlik açısından da ele alınması önemli bir konu haline gelmektedir. Sürdürülebilirlik kavramı, son zamanlarda pek çok alanda olduğu gibi dijital sağlık hizmetleri alanında da yine akademik çalışmalara konu olmuştur (Asi ve Williams, 2018; Faggini, Cosimato, Nota ve Nota, 2018; Mburu ve Kamau, 2018; Novillo-Ortiz, Marin, ve Saigí-Rubió, 2018; Presti, Testa, Marino, ve Singer, 2019; Tongue, 2019; Yıldız, 2016). Dijital sağlık hizmetlerinde meydana gelen hızlı ivme ve gelişmeler bu kavramın sürdürülebilirlikle bağlantısını da önemli hale getirmektedir.

Birleşmiş Milletler, 2015 senesinde 17 adet sürdürülebilir kalkınma hedefi açıklamıştır (BM, t.y.). Hedefler dikkatlice incelendiğinde dijital sağlık hizmetlerinin bu hedeflerden bazılarıyla açık bir şekilde ilişkisi olabileceği görülmektedir. Bunlardan biri, sağlıklı yaşamlar sağlamaya ve her yaştaki insanlar için refahı teşvik etmeye çalışan "Hedef 3: Sağlıklı ve Kaliteli Yaşam" dır. "Hedef 10: Eşitsizliklerin Azaltılması" ile ülkelerin kendi içinde ve de ülkeler arasında eşitsizliklerin azaltılması hedeflenmektedir. Öte yandan Sherman ve diğerleri, 2020 makalelerinde geleneksel sağlık hizmetlerinin sağlı̆ııııı olumsuz yönde etkileyen çevresel kirletici maddelerin yayıcısı olduğunu belirtmektedir. Bu aynı zamanda iklim değişikliği ve etkileriyle mücadele için acil önlem almaya çalışan "Hedef 13: İklim Eylemi" ile de ilgilidir.

Bu makalede özellikle sürdürülebilirlik kavramı ve Birleşmiş Milletler 'in "Sürdürülebilir Kalkınma Hedefleri" kapsamında dijital sağlık hizmetlerinin daha iyi anlaşılmasının yanısıra dijital sağlık hizmeti sağlayıcılarının sundukları dijital sağlık hizmetlerinin sürdürülebilirliğe olan katkılarının ortaya çıartılarak değerlendirilmesi amaçlanmaktadır. Sürdürülebilirlikle ilgili zorlukların birçoğunun yeterince araştırılmamış olması nedeniyle, bu makale, bazı dijital sağlayıcılar (örneğin, dijital teknolojiler ve platformlar) tarafından desteklenen, sağlık hizmetleri gibi 
karmaşık hizmet sistemlerinin sürdürülebilirliğini artıran sistem dinamiklerinin bu hedeflere katkısının daha iyi anlaşılmasını sağlamayı hedeflemektedir.

\section{Dijital Sağlık Hizmetleri}

Günümüzde dijitalde yaşanan mevcut gelişmeler devrim niteliğinde sayılabilecek derecedeler ve bu gelişmeler, sağlik hizmetlerinin sunumunu da yeni bir çağa doğru itiyor. Ayrıca hastaların da eski zamanlara göre daha bilgili olmaları sebebiyle daha güçlü bir hale gelmelerinin yanı sıra sağlık hizmetlerinde meydana gelen bu yapısal değişikliklerle de geleneksel, hiyerarşik yüz yüze sağlık hizmetlerinde dönüşüm çoktan başlamıştır. Bu konuda ilklerden olan Seth Frank, 2000 senesinde yazmış olduğu makalesinde, internetin ve internet tabanlı uygulamaların daha önceki bilgi teknolojileri ve iletişim araçlarına kıyasla sağlık hizmetleri üzerinde daha hızlı, önemli, pozitif ve de ölçülebilir bir etkiye neden olacağını iddia etmiştir.

E-sağlık (elektronik sağlık) ya da dijital sağlık terimi, elektronik sağlık, sağlıkla ilgili hizmet ve süreçlerde bilgi ve iletişim teknolojilerinin (BİT) kullanımı için genel bir şemsiye terim olarak kullanılıyor (Wernhart, Gahbauer, ve Haluza, 2019). Dünya çapında modern sağlık sistemleri için çok önemli hale gelen dijital sağlık hizmetleri terimi genom bilimi, yapay zekâ, analitik, giyilebilir teknolojiler, mobil uygulamalar ve teletıp gibi çok daha geniş bir bilimsel kavram ve teknolojileri kapsayacak şekilde genişledi (Mathews vd., 2019).

Dijital sağlık çözümleri sayesinde 21. yüzyılda sağlık hizmetlerinin sunulma şekli sistematik olarak dönüşmeye başladı. Tele tıp gibi dijital teşhis çözümleri ile hastalar daha kolay bir şekilde uzaktan ve geleneksel yollara göre bazen daha hızlı teşhis alabilirken, bazı akıllı telefon uygulamaları hastalara diyabetten depresyona kadar değişen durumlar için etkili tedavi, hastalık önleme veya hastalık yönetimi çözümleri sunabiliyor. Özellikle uzaktan sağlık hizmeti alabiliyor olmak, aynı ülke içerisinde farklı şehirde bulunan bir hasta ile doktoru ya da farklı ülkelerde bulunan bir hasta ile doktoru da sinırları ortadan kaldırmak suretiyle birleştirebiliyor. Tüm bunlar aslında dijital sağlık hizmetleri kapsamında ele alınabilecek hizmetler arasında bulunmaktadır. 
Dijital sağlık hizmetlerinin sunulması için kullanılan dijital sağlık teknolojilerinden bahsedildiği zaman yukarıda da zaman zaman bahsedildiği üzere, çok geniş çerçevede dijital sağlık kayıtlarından mobil sağlık hizmetlerine, yapay zekâ uygulamalarından tele tıp ve giyilebilir teknolojilere kadar pek çok konsept gündeme gelmektedir (Bektaş ve Şimşek, 2016). Bu noktada kavramlar arası ayrımı yapmakta fayda bulunuyor. Tele tıp, klinik hizmetlerin, doktorların sağlık hizmetlerini uzaktan sunmasını sağlamak için bilgi teknolojilerinden, video görüntülemeden ve telekomünikasyon bağlantılarından yararlanması olanak tanımlanıyor. Bir doktor tarafından uzaktan tıbbi hizmetlerin sağlanması olarak dar bir şekilde tanımlanan tele tıpın aksine, tele-sağlık, tele tıp ve teleeğitim ve tele farmasi dahil olmak üzere çeşitli, doktorlar dışında sağlık hizmetleri sunan kişilerin verdikleri hizmetleri kapsayan şemsiye bir terimdir. Mobil sağlık ise, kablosuz hasta izleme cihazları, akıllı telefonlar, kişisel dijital asistanlar ve tablet bilgisayarlar gibi mobil iletişim cihazları tarafından desteklenen hizmetleri tanımlayan daha yeni bir kavram olarak ortaya çıkmaktadır (Weinstein vd., 2014). Dolayısıyla tele tıp kapsamına giren hizmetlerin hepsi mobil cihazlar üzerinden yapılabilir konumdadır, mobil sağlık tele tıpı da kapsayan bir kavram haline gelmektedir.

$\mathrm{Bu}$ terimleri biraz daha derinlemesine inceleyecek olursak: Dünya Sağlık Örgütü'nün (WHO) tanımına göre tele tıp; mesafenin kritik bir faktör olduğu durumlarda, bireylerin ve toplumların sağlığını iyileştirmek için sağlık profesyonellerinin, hastalıkların ve yaralanmaların teşhisi, tedavisi ve önlenmesi ile araştırma, değerlendirme ve sürekli eğitim konularında, bilgi ve teknolojiyi kullanarak sağlık hizmeti vermesidir (WHOa, 2010). Temel olarak, tele tıp terimi, hastalar ve sağlık hizmeti sağlayıcıları aynı yerde bulunmazken, sağlık hizmetlerinin BİT destekli sağlanmasını ifade eder. Bunda kendi başına hassas içerik olarak algılanan metin, ses ve görüntü temelli tıbbi verilerin güvenli bir şekilde iletilmesini sağlamak, tıbbi önleme, teşhis, tedavi ve takip için bir ön koşuldur (Wernhart vd., 2019).

Mobil sağlık hizmetleri, eczane uygulamalarından tele tıp uygulamalarına kadar akıllı telefonlarda kullanılan çok çeşitli uygulamaları içeren geniş bir terimdir. Mobil sağlık, Tezcan'a (2016) göre “cep telefonlarının temel fonksiyonlarından ses ve kısa mesaj servisleri/SMS, GPRS, GPS 
(lokasyon belirleme), üçüncü ve dördüncü nesil (3G, 4G, LTE) iletişim sistemleri ve Bluetooth, NFC teknolojileri gibi daha karmaşık fonksiyon ve uygulama modellerini" kullanmaktadır. Mobil sağlık hizmetlerinin en büyük avantajı, genel olarak dijital sağlık hizmetlerinde olduğu gibi teknolojinin hastaların sürece daha aktif bir şekilde dahil olmasına izin vermesidir. 2019 senesinde mobil sağlık hizmetleri 37milyar dolarlık bir pazara sahipti, 2021 senesinin sonuna kadar ise 100 milyar dolarlik bir pazara ulaşması beklenmektedir. Doktorların \%93'ü ise mobil sağllk hizmetlerinin hastaların sağlıklarına katkı sunacağına inanmaktalar (Gromenko, 2021). Tele tıp da literatürde mobil sağlık hizmetleri kapsamında ele alınmaktadır (Bektaş ve Şimşek, 2016). Bahsedilen terimlerden özellikle tele tıp ve mobil sağlık hizmetleri bu çalışma kapsamında dijital sağlik hizmetlerinde özellikle kastedilen iki terimdir. Bu iki kavramın tanımlarından da anlaşılacağı üzere çok iç içe geçmiş kavramlardır, çünkü tele tıp son zamanlarda özellikle mobil cihaz kullanımındaki artışla beraber yüksek bir ivme kazanmıştır.

Dijital sağlık hizmetlerinin kullanımındaki artışı gösteren pek çok veri bulunmaktadır. Bunlardan bir tanesi de mobil sağlık aplikasyonları/uygulamaları olarak gösterilebilir. Statista tarafından yayınlanan bir veriye göre 2015'in ilk çeyreğinden 2020 son çeyreğine kadar Google Play'de bulunan mobil sağlık aplikasyon sayısındaki değişim dikkate değerdir. 2018 son çeyreğinde uygulama sayısı azalsa da sonrasında artan bir oranda her çeyrekte piyasaya sunulan uygulama sayısındaki artış gözlenmektedir (bkz: Şekil 1).

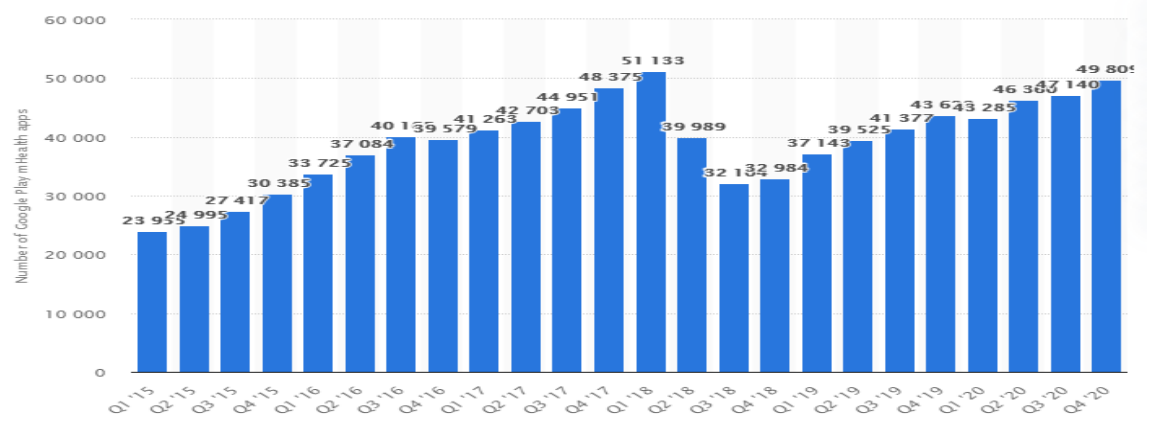

Şekil 1. 2015 ilk çeyreğinden 2020 son çeyreğine kadar Google Play'de bulunan mobil sağlik aplikasyon sayıs (Kaynak: https://www.statista.com/statistics/779919/health-apps-availablegoogle-play-worldwide/) 
Deloitte'un 2021 Global Sağlik Raporu'nda da belirtildiği gibi COVID-19 salgını 2020 yılında sağlık hizmetleri kapsamında ele alındığında dijital teknolojilerin itici gücü haline gelmiştir. Çünkü salgınla birlikte sağlık hizmet talebi ile arzı arasındaki boşluk tüm dünyada hızla artmıştır. Bu boşluk özellikle sağlık personeli ve pek çok fiziksel kaynak manasında ortaya çıarken, bu meydana gelen boşluğu kapatmak için dijital sağlık hizmetlerinin kritik önemi pek çok insan tarafından fark edilmiş durumdadır. Ayrıca, pek çok mobil aplikasyon da bu süreçte salgının da etkisi ile daha hızlı bir şekilde piyasada yer bulmuştur.

Aynı raporda (Deloitte, 2021) sağlık hizmetleri ekosisteminde dijital dönüşümün COVID-19 ile birlikte nasıl bir ivme kazandığ1 yönünde de bazı istatistiklere yer verilmiş durumdadır. Buna göre, birçok $A B$ ülkesindeki 1800 sağlık çalışanı ile yapılan çalışma sonucunda, bu çalışmaya katılanların \%64,3'ü çalıştıkları hastanelerin hastalara sanal destek verebilmek ve de onlarla etkileşimde bulunabilmek için dijital teknolojilere adaptasyonlarını artırdıklarını belirtmişlerdir.

Dijital sağlık teknolojilerinin kullanımı her ne kadar artsa ve de buna dahil olmaya çalışan kurumlar çoğalsa da bu konunun önünde bazı engellerin olduğu da muhakkaktır. Bu engeller arasında en çok görülen zorluklar ise şu şekilde sayılabilir: Sağlık hizmetlerinde bürokrasi, teknolojilerin maliyeti, doğru teknolojileri bulmanın zorluğu ve dijital teknolojileri kullanma konusunda personel eğitimi eksikliği (Deloitte, 2021).

\section{Türkiye'de Dijital Sağlık}

Sağlık Bakanlığı, 2003 senesinden bu yana sağlık sisteminde iyileştirmelere gitmek amacıyla Sağlıkta Dönüşüm Projesi'ni başlattı. Bunun altında yatan temel gerekçe Dünya Sağlık Örgütü'nün (WHO) “Bir ülkenin sağlık sistemi, herkese gerekli olan sağlık hizmetinin yüksek kalitede verilmesini sağlayacak şekilde tasarlanmalıdır. Bu hizmeti etkili, karşılanabilir maliyette ve toplumca kabul gören tarzda olmalıdır. Her ülkenin bu faktörleri göz önünde tutarak kendi özgün sağlık sistemini geliştirmesi önerilmektedir" tavsiyesi yer almaktadır (Akdağ, 2012).

Sağlıkta Dönüşüm Projesi öncesinde 1990l'1 senelerde başlatılan Türkiye'deki tüm hastanelerin ortak bir ağa bağlanması ve Hastane Bilgi Yönetimi Sistemi'nin (HBYS) devreye girmesi planlanmış, ancak bu 
2010'lu yıllar itibariyle mümkün olabilmiştir. HBYS “bilgisayar programları ve etkileşim içinde olduğu hastanelerin yapmış olduğu işlemleri bilgisayar üzerinde gerçekleştiren yazılımlar grubuna verilen genel addır." olarak tanımlanmaktadır (Dijital Hastane, 2015). Devam eden süreçte bu doğrultuda sağlığın dijitalleşmesi amacıyla pek çok farklı sistem devreye girmiştir. Bunlar; Ulusal Sağlık Veri Sözlüğü (USVS), Aile Hekimi Bilgi Sistemi (AHBS), Elektronik Belge Yönetim Sistemi (EBYS), Engelsiz Sağlık İletişim Merkezi (ESIMM), İlaç Karar Destek Sistemi (IKDS), Kişisel Sağlık Sistemi (e-Nabız), Merkezi Hekim Randevu Sistemi (MHRS), Sporcu Sağlığı Bilgi Sistemi (SSBS) olarak sayılabilir (Peker, Giersbergen ve Biçersoy, 2018).

Devlet tarafından sunulan sağlık hizmetlerinin dijitalleşme sebeplerinden birisi daha fazla ve daha sağlıklı veri elde etmek suretiyle, tıbbi karar verme süreçlerinin iyileştirilmesiydi, Karar Destek Sistemi (KDS) de bu kapsamda devreye alınmış bir sistemdir (Kılınç Hukuk, 2020). Buraya kadar bahsedilen uygulamalar aslında Elektronik Sağlık Kaydı (ESK) tutulması bağlamında değerlendirilebilecek; doktordan randevu alma, hastanelere teşhis ya da tedavi için gittiğimi zaman yapılan işlemlerin kaydının tutulması gibi işlemlerin yer aldığı bilgi toplumu ve edevlet kapsamındaki uygulamalardır denilebilir. Yani bir nevi devlet tarafından sunulan sağlık hizmetlerinin dijitalleşmesi üzerine dayanmaktadır, başka bir ifade ile bu hizmetler kamu tarafından sunulan sağlık hizmetlerinin gün geçtikçe daha da teknoloji temelli olmasını ifade etmektedir.

AB Sağlık Komisyonu e-sağlık hizmetleri içerisinde tele tıp ve mobil sağlık başta olmak üzere robotik uygulamalar, dijital hastane ve büyük veri/elektronik sağlık kayıtları olarak beş bileşenden bahsetmektedir (Kosif, 2019). Burada daha önce bahsedilen kavramlardan farklı olarak dijital hastane karşımıza çıkmaktadır. Ak (2013, s.973) dijital hastaneyi detaylı olarak şu şekilde tanımlamıştır: "Sağlık kurumu/hastane içerisindeki tüm bilgi sistemlerinin medikal ve medikal olmayan her türlü teknolojilerle tam entegre olduğu, güvenilir veri akışı standartlarının belirlendiği, hekim, hemşire vb. personele yetkileri çerçevesinde çok daha az zaman ve enerji harcayarak hastane ve hasta verilerine ve bilgilerine her yerden, yer bağımsız olarak mobil olarak erişimini sağlayan, el ile işlem yapılmayan, kağıtsız ve filmsiz olarak çalışan, sağlık görevlilerinin iş 
süreçlerini etkili hale getiren, doğru ilaç ve medikal tedavi uygulamalarının kontrol edildiği, gerçek anlamda bütün işlemlerin tam otomasyon sistemi ile yapıldığı, kontrol edildiği, yönetildiği bir hastane işleyişine ve ileri teknoloji donanımına sahip, hastane çalışanlarına, hastalara ve yakınlarına etkili, verimli, ekonomik, erişilmesi mümkün ve kaliteli sağlık hizmeti sunmaya hedeflenmiş, üçüncü taraflar, e-sağlık ve e-devlet ile de tam entegre hastanelere dijital hastane denilmektedir". Türkiye, dijital hastane kapsamında değerlendirildiğinde, Avrupa'da oldukça iyi bir konumdadır (Kosif, 2019).

Sağlıkta dijital teknolojilerin ve dijitalleşmenin kapsamı görüldüğü gibi oldukça geniş bir çerçevede ele alınmaktadır. Ancak, dijital ortamlarda tüm kayıtların tutulması ve de bu kayıtlara tüm sağlık çalışanlarının ve de sağlık merkezlerinin ulaşmasından ziyade doğrudan hastalar ile etkileşime geçilmesi gibi bir durum daha çok mobil sağlık hizmetleri ile gerçekleşmektedir. Bu çalışmada da ele alınan dijital sağlık hizmetleri kapsamı daha çok hasta ile sağlık çalışanlarını bir araya getiren mobil sağlık hizmetleridir. Tele tıp hizmetleri de mobil sağlık kapsamında ele alınabilmektedir, bunu da daha önceki başlıkta belirtmiştik, dolayısıyla çalışmamız dijital sağlık hizmetlerini her iki terim kapsamında ele alınmaktadir.

Dijital sağlık hizmetine erişim ve kullanım da ancak kişiler Bilgi İletişim Teknolojilerine-BİT (ICT) erişebiliyorsa mümkündür. Türkiye, gelişmekte olan bir ülke olarak ele alındığında internet kullanım oranları her sene ciddi manada yükseliş göstermektedir. İnternet kullanımı ve internete erişim oranlarına TÜİK Hanehalkı Bilişim Teknolojileri Kullanım Araştırması verilerinden bakıldığında 2020 Ağustos itibari ile 16-74 yaş grubunda yer alan bireylerin $\% 79^{\prime}$ u interneti kullanmaktadır. İnternet kullanan bireylerin ise \%90,7'si evden internet erişim imkanına sahiptir. Bu arada bireylerin internet kullanım amaçlarına bakıldığında $\% 65,4^{\prime}$ ü interneti sağlıkla ilgili bilgi aramak amacıyla kullandıklarını belirtmişler (TÜİK, 2020). Dolayısıyla, bu veriler ışığında Türkiye'deki geniş BİT kapsamı nedeniyle, dijital sağlık hizmeti kullanımının yaygınlaşması potansiyelinin umut verici ve keşfedilmeye değer olduğu görülmektedir. 


\section{Türkiye'de Kullanılan Bazı Mobil Sağlık Uygulamaları}

2018 yılında IPSOS tarafından 28 ülkeden 23.249 kişinin katılımıyla gerçekleştirilen bir araştırma sonucunda Türkiye'nin dijital sağlık hizmetlerine en hevesli üç ülke arasında yer aldığı sonucuna varılmıştır (Dünya Gazetesi, 2018). Bu çalışmadan bu yana geçen 3 sene içerisinde yaşanan gelişmeler ile internet kullanım oranları ve de amaçları da düşünüldüğünde ülkece aslında bu teknolojileri kullanmaya hazır olduğumuzu da söylemek mümkün hale gelmektedir. Türkiye'de mobil sağlik hizmetleri kapsamında özellikle özel hastaneler COVID-19 döneminde çok büyük sıçrayış yaparak pek çok uygulamayı kullanıma sunmuştur. Bu alanda özel hastaneler ve özel hastaneler haricinde sunulan tele tıp ve mobil sağlık alanındaki uygulamaları özetleyecek olursak:

- Doctor Turkey: Bu platform, Türk Telekom bünyesinde geliştirilen, hastaların sağlık profesyonellerine günün her saati ulaşabildikleri Türkiye'nin ilk videolu görüşme hizmeti olarak tanımlanmaktadır. Bulunulan yerden bağımsız olarak istenen zamanda doktorlarla canlı görüşme hizmeti sunmaktadır (https://www.doctorturkey.com.tr/).

- Telemedico: DocPlanner Grup tarafından hayata geçirilen yurtdış1 merkezli bir dijital sağlık uygulamasıdır. Hem mobil cihazınızdan hem de bilgisayarınızdan chrome tarayıcısı ile doktorlarla görüntülü görüşme imkânı sunmaktadır. Ücretlendirme kısmında TL bulunmadığı için biraz pahalı sayılabilir (https://telemedi.co/tr/).

- CCR Easy Connect Video: Hem bankacılık hem de sağlık alanında görüntülü görüşme imkânı sunan bir uygulamadır. Dosya ve ekran paylaşımını da desteklemektedir. Hem mobil işletim sistemleri hem de tarayıcılar desteklemektedir. Bu sistemi doğrudan kullanmaktan ziyade sağlık kuruluşlarının sistemlerine entegre ederek kendi uygulamalarını hayata geçirmeleri için kullanabilecekleri söylenebilir (https://www.ccr.group/easyconnect-video/).

- Acıbadem Evinizde: Acıbadem Grubu'nun sunmuş olduğu dijital sağlık uygulaması da online doktor görüşmesi sağlayarak hastaneye gelmeden tanı ve tetkik işlemi yapılmasına imkan vermektedir. Uzaktan online görüşme sırasında doktorun fiziksel muayeneyi zorunlu görmesi halinde hasta, hastaneye davet edilmektedir. Doktorlarla görüşmeyi WhatsApp, FaceTime ya da Skype gibi platformlar- 
dan hangisi üzerinden gerçekleştirmek isteniyorsa seçim imkânı vermektedir. (https://www.acibadem.com.tr/acibadem-evinizde/).

- Medicana Online Hekim: Medicana Sağlık Grubu doktorlarına ulaşmaya imkân veren mobil uygulama sayesinde diğer hastane uygulamalarında olduğu gibi yerden ve zamandan bağımsız olarak canlı online görüşmeler gerçekleştirilebilmektedir, ayrıca web sitelerinde bu uygulamanın kullanımı, görüşme süresi, ücretlendirme ve ödeme konusunda detaylı bilgiler bulunmaktadır (https://www.medicana.com.tr/OnlineHekim).

- Memorial E-Doktor: Memorial Grubu'nun bireylerin hastane ortamina girmeden doktorları ile video konferans yoluyla iletişime geçmelerini sağlayan uygulaması tarafından pandemi başladıktan hemen sonra devreye alınmış bir hizmettir. Bu hizmet hastaneye özel geliştirilen bir uygulamadan değil WhatsApp ve FaceTime üzerinden verilmektedir. Web sitelerinde uygulama kullanılırken çekilen fotoğraflar ve doktorların uygulama hakkında bilgi verdikleri videolar yer almaktadır https://www.memorial.com.tr/memorial evinizde).

- Medical Park Görüntülü Doktor Görüşmesi: Medical Park Hastaneler Grubu da doktorlarla online ortamda, uygulamaları üzerinden uzaktan video görüşme imkânı sunmuştur. İlgili web sitesinde uygulama detayları ve kullanımı hakkında detaylı bilgilendirme gerçekleştirilmiştir (https://www.medicalpark.com.tr/online-doktorgorusmesi/n-230).

- Florence Nightingale Online Tıbbi Danışma: Florence Nightingale mobil sağlık hizmetini geliştirilen bir aplikasyon üzerinden değil, WhatsApp uygulaması üzerinden vermektedir. Hastalar randevu taleplerini çağrı merkezinden oluşturarak randevu alıp ilgili doktorla görüşme imkânı bulabiliyorlar (https://online.florence.com.tr/).

- Hizmet Hastanesi E-Doktor: Hizmet hastanesi de Florence Nightingale ile benzer şekilde online görüntülü görüşme imkanını Whatsapp ve FaceTime uygulamaları üzerinden gerçekleştirmektedir. Kendilerine özel bir uygulama yazılımı bulunmamaktadır (https://www.hizmethastanesi.com/kampanyalar/hizmet-hastanesi-edoktor/). 
- Miaclinics E-Doktor: Klinik hizmeti veren kuruluş, bünyesinde yer alan İç Hastalıkları ve Obezite Uzmanı \& Sağlıklı Yaşam ve Beslenme Koçu ile Bölgesel İncelme ve Ağrı Yönetimi uzmanı doktorlarla WhatsApp ve FaceTime uygulamaları üzerinden canlı görüşme imkânı sunmaktadır (https://miaclinics.com/e-doktor-ve-goruntuludoktor-gorusmesi/).

- Kent Online Doktor: Yerel hastanelerden biri olan İzmir'deki Kent Sağlık Grubu bünyesinde doktorlarla online görüşme imkânı sunulmaktadır, sadece mesai saatleri içerisinde WhatsApp üzerinden görüşme yapma imkanı verilmektedir (https://www.kentsaglikgrubu.com/online-doktor.html).

- Denizli Özel Sağlık Hastanesi Sağlık Evinizde: Denizli'de faaliyet gösteren yerel hastanelerden olan Denizli Özel Sağlık Hastanesi, diğer hastanelerle benzer bir şekilde doktor muayenesini ya da tedavisini uzaktan olmak isteyen bireylere mobil sağlık hizmeti sunmaktadir. Görüşmeyi WhatsApp, FaceTime ya da Skype gibi platformlardan görüme yapmaya imkân vermektedir (https://www.saglikhastanesi.com.tr/saglik-evinizde/).

- Anadolu Sigorta 7/24 Sağlık Danışmanlığı: Anadolu Sigorta kapsaminda olan bireysel ve kurumsal sigortalıların "Sağlığım Cepte" aplikasyonundan ya da "Anadolu Sigorta online şubesi" vasitasiyla, canlı ve görüntülü görüşme yapabilmesine imkan veren mobil sağlık hizmeti (https://www.anadolusigorta.com.tr/medyada-biz/basinbultenleri/anadolu-sigortadan-7-24-canli-ve-goruntulu-saglikdanismanligi-hizmeti) .

- Ada Sigorta Canlı ve Görüntülü Sağlık Danışmanlı̆̆ı Hizmeti: Bahsedilen diğer uygulamalarla benzer şekilde sağlık sigortası hizmetinden yararlanan bireyler için $7 / 24$ ve ücretsiz görüntülü doktor hizmeti sunmaktadır. Bu hizmeti "Sağlığım Cepte" aplikasyonu üzerinden vermektedir (https://www.adasigorta.com.tr/sayfa-canli-vegoruntulu-saglik-danismanligi-hizmeti-8).

Bunlara ek olarak sayılabilecek diğer uygulamalar arasında İstanbul Teknik Üniversitesi (İTÜ) Çekirdek girişimlerinden Bulutklinik, Arabisor, Lokman Hekim sayılabilir. Sigorta şirketlerinden Tur Assist, Axa Sigorta yerel hastanelerden Trabzon'da faaliyet gösteren İmperial Hastanesi, Antalya'da faaliyet gösteren Medstar Hastane Grubu da benzer 
şekilde mobil sağlık hizmeti vermektedir. Sayılan uygulamalar arasında Google Play ya da Apple Store'da yer alan aplikasyonların indirme say1ları ve de puanlamalar, yorumlara bakılarak bu hizmetler hakkında fikir sahibi olma ihtimali bulunurken, diğer uygulamalar üzerinden dijital sağlık hizmeti veren kuruluşların durumu hakkında fikir sahibi olmamız pek mümkün görülmemektedir. Ancak, özellikle her kuruluşta uygulamalar hakkındaki açılamalarda yer alan COVID-19 vurgusu, salgınla birlikte verilen dijital sağlık hizmetleri kapsamında tele tıp ve mobil sağlık hizmetlerinin yükselişte olduğunu kanıtı niteliğindedir.

Ayrıca bu uygulamalarda dikkat çeken başka bir nokta da daha önce Deloitte'un 2021 raporunda da belirttiği gibi dijital sağlı uygulamalar1nın uygulanma noktasında karşılaştığı bazı engeller arasında sağlık hizmetlerinde bürokrasi, teknolojilerin maliyeti, doğru teknolojileri bulmanın zorluğu ve dijital teknolojileri kullanma konusunda personel eğitimi eksikliği noktalarına vurgu yapılmıştır. Burada da bazı hastanelerin halihazırda mobil aplikasyonları olmasına rağmen entegrasyon yapmamaları ve mobil sağlık hizmetini bazı üçüncü taraf uygulamalarla (WhatsApp, Skype, FaceTime gibi) veriyor olmaları da burada maliyet ve teknoloji kullanımı noktasında personel eğitim eksikliği unsurlarını akla getirmektedir.

\section{Sürdürülebilirlik ve Sürdürülebilir Kalkınma Hedefleri}

Alman muhasebeci ve maden işletmecisi Hans Carl von Carlowitz'in orman alanlarının korunmasına kadar uzanan "sürdürülebilirlik" kavramı çok genel ve basit olarak "herhangi bir şeyin belli bir süre boyunca azalmadan kalabilmesi" olarak tanımlanmaktadır (SKD Türkiye, 2016). Başka bir tanıma göre ise sürdürülebilirlik "bugünün ihtiyaçlarını karş1larken doğal kaynakları korumak ve gelecek nesillere iyi bir çevre bırakmak için yapılan faaliyetlerdir" (Kuter ve Ünal, 2009; s.147)

Sürdürülebilir kalkınma anlayışı ise, "sürdürülebilirlik" kavramını ülkelerin ekonomik ve sosyal gelişme hedeflerinde ortak payda olarak belirlemektedir (T.C. Cumhurbaşkanlığı Strateji ve Bütçe Başkanlığı, t.y.). Sürdürülebilir Kalkınma Birliği'ne göre ise sürdürülebilir kalkınma "gelecek nesillerin kendi ihtiyaçlarını karşılama yeteneklerinden ödün 
vermeden bugünün ihtiyaçlarını karşılayan bir gelişimdir" (WCED, 1987; s.43).

Birleşmiş Milletler (BM) 193 üye devlet tarafından gerçekleştirilmesi ve dünya kalkınma hedeflerinde ilerleme sağlanması amacıyla 2000-2015 yılları arasında Milenyum/Binyıl Kalkınma Hedefleri belirlemiştir (Asi ve Williams, 2018). Milenyum/Binyıl Kalkınma Hedeflerinin çoğuna ulaşmada devletlerin başarılı olduğu görüldü. İkinci olarak ise 2015-2030 seneleri arasında geçerli olacak şekilde Sürdürülebilir Kalkınma Hedefleri yine BM tarafından belirlenmiştir. Bu hedefler ile Milenyum/Binyıl Kalkınma Hedeflerinin daha da ileriye taşınması amaçlanmaktadır.

O dönemin BM Genel Sekreteri Ban Ki-moon bu hedefleri tanımlarken şu cümleyi söylemiştir: "Küresel yoksulluğu sona erdirmek, herkes için haysiyetli bir yaşam inşa etmek ve kimseyi geride bırakmamak için bir yol haritasıdır. Aynı zamanda ortaklık içinde çalışmaya ve refahı paylaşmak, insanların geçim kaynaklarını güçlendirmek, barışı sağlamak ve gezegenimizi bunun ve gelecek nesillerin yararına iyileştirmek için çabaları yoğunlaştırmaya yönelik açık bir çağrıdır." ～(BM Sürdürülebilir Kalkınma Zirvesi - Basın Bülteni, 2015).

On yedi tane belirlenen Sürdürülebilir Kalkınma Hedeflerinin temelde üç amacı bulunuyor, bunlar: Aşırı yoksulluğu sona erdirmek; eşitsizlik ve adaletsizlik ile mücadele etmek; iklim değişikliğini önlemek ve uyum (SKD Türkiye, 2016). Sürdürülebilir Kalkınma Hedeflerinin hepsini listeleyecek olursak;

Tablo 1: BM Sürdürülebilir Kalkınma Hedefleri (Kaynak: https://sdgs.un.org/goals)

Sürdürülebilir Kalkınma Hedefleri / Türkçeleştirilmiş Versiyonları

Hedef 1: Yoksulluğa Son

Hedef 2: Açlığa Son

Hedef 3: Sağlıklı ve Kaliteli Yaşam

Hedef 4: Nitelikli Eğitim

Hedef 5: Cinsiyet Eşitliği

Hedef 6: Temiz Su ve Sanitasyon

Hedef 7: Erişilebilir ve Temiz Enerji

Hedef 8: İnsana Yakışır İş ve Ekonomik Büyüme

Hedef 9: Sanayi, Yenilikçilik ve Altyapı
Sürdürülebilir Kalkınma Hedefleri /

BM Tarafından Açıklanan Orijinal Versiyonları

Goal 1: No Poverty

Goal 2: Zero Hunger

GOAL 3: Good Health and Well-Being

Goal 4: Quality Education

Goal 5: Gender Equality

Goal 6: Clean Water and Sanitation

Goal 7: Affordable and Clean Energy

Goal 8: Decent Work and Economic Growth

Goal 9: Industry, Innovation and Infrastructure 
Hedef 10: Eşitsizliklerin Azaltılması Hedef 11: Sürdürülebilir Şehirler ve Topluluklar

Hedef 12: Sorumlu Tüketim ve Üretim

Hedef 13: İklim Eylemi

Hedef 14: Sudaki Yaşam

Hedef 15: Karasal Yaşam

Hedef 16: Barış, Adalet ve Güçlü Kurumlar

Hedef 17: Amaçlar için Ortaklıklar
Goal 10: Reduced Inequality

Goal 11: Sustainable Cities and Communities Goal 12: Responsible Consumption and Production

Goal 13: Climate Action

Goal 14: Life Below Water

Goal 15: Life on Land

Goal 16: Peace and Justice Strong Institutions Goal 17: Partnerships to Achieve the Goal

On yedi tane belirlenen kalkınma hedefinin altında toplamda 169 kendi alt hedefleri ve bunları ölçebilmek için indikatörleri/göstergeleri de bulunmaktadır. T.C. Cumhurbaşkanlığ 1 Strateji ve Bütçe Başkanlığ 1 tarafından 2020 senesinde hazırlanan "2019 Sürdürülebilir Kalkınma Amaçları Değerlendirme Raporu"na göre Türkiye'nin daha önceki politika ve uygulamalara aşina olduğu, bilgi birikimi manasında yeterli, kuruların da hazır olduğu vurgulanmaktadır. Ayrıca, yapılan mevcut durum analizine göre ise birçok sürdürülebilir kalkınma hedefi açısından dünya ortalamasının üzerinde bir noktada yer aldığı belirtilmektedir. Sürdürülebilir kalkınma hedeflerinin gerçekleştirilmesi kapsamında yapılması gereken çalışmalar ve bu çalışma alanlarının neler olması gerektiği konusunda maddeler raporda özetlenmektedir. Bu maddeler arasında özellikle bilgi teknolojilerinin gelişiminin desteklenmesi, engelli ve diğer dezavantajlı grupların kapsanması için yerel yönetimlerin harekete geçirilmesi ile temel hak ve özgürlüklerle kamu hizmetleri etkinliğinin geliştirilmesi gibi konular bir sonraki bölümde ele alınacak olan sürdürülebilir kalkınma hedefleri ve dijital sağlık hizmetleri kapsamında dikkate değerdir.

\section{Sürdürülebilir Kalkınma Hedefleri ve Dijital Sağlık Hizmetleri}

2020 senesinden bu yana yaşanan COVID-19 salgını sebebi ile sağlık hizmetlerine ulaşmak oldukça zorlaşmış, dolayısıyla dijital sağlık hizmetlerinin önemi daha da artmıştır. Özellikle kronik hastalıkları bulunan ve de sağlık uzmanları ile sıklıkla iletişimde bulunması gereken hastalar göz önünde bulundurulduğunda dijital sağlık hizmetleri hastaların semptomlarının ve teşhislerin izlenmesi için etkili bir yöntemdir. Ancak 
günümüzde bu hizmetlerin herkes için erişilebilir hale getirmenin önünde duran dijital eşitsizlikler de bulunmaktadır (Khilnani, Schulz ve Robinson, 2020).

Dünya Sağlık Örgütü (WHO) “Dijital Sağlıkta Küresel Strateji 20202025" raporunda 2030 Sürdürülebilir Kalkınma Gündemi, bilgi ve iletişim teknolojisinin yayılmasının ve küresel olarak birbirine bağlılığın insan ilerlemesini hızlandırmak, dijital uçurumu kapatmak ve bilgi toplumlarını geliştirmek için büyük bir potansiyele sahip olduğunu vurguluyor. Ayrıca, yine bu noktada şunu da belirtmekte fayda bulunmaktadır: BM Sürdürülebilir Kalkınma Hedefleri Zirvesi'ne katılan bakanlar ve heyet başkanları, sağlıkla ilgili Sürdürülebilir Kalkınma Hedeflerinde ilerlemeyi hızlandırabileceklerini belirterek, 2030 Sürdürülebilir Kalkınma Gündemi'ne ulaşmak için bilgi ve iletişim teknolojilerinin potansiyelinden yararlanmayı taahhüt ettiler. Dolayısıyla tele tıp, mobil sağlık gibi sağlık teknolojilerini geliştirmek bu hedeflere ulaşmada çok önemli hale gelmektedir. Bu uygulamalar özellikle dünyanın az gelişmiş ülkelerinde bulunan, ya da gelişmiş ülkelerde yaşasa bile sağlık hizmetlerine erişimde günümüzde olduğu gibi ekstrem durumların da sebebiyle ulaşamayan, aynı zamanda doğal afetlerde nitelikli sağlık hizmeti sunmak amacıyla geliştirilmiş olsa bile, son 60 senede çok çeşitli uygulama alanı bulmuştur (Özge ve Uludüz, 2020).

Aynı raporda belirtildiği üzere küresel sağlık camiasında, bilgi ve iletişim teknolojilerinin 17 Sürdürülebilir Kalkınma Hedefinin tamamının başarılması için yeni fırsatlar ve zorluklar sunduğu kabulüyle dijital ve en ileri bilgi ve iletişim teknolojilerinin stratejik ve yenilikçi kullanımının daha fazla insanın daha iyi, sağlıklı ve kaliteli yaşam koşullarından yararlanmasını sağlamaya yönelik önemli bir kolaylaştırıcı faktör olacağ yönüne artan bir fikir birliği bulunmaktadır.

Sürdürülebilir kalkınma hedeflerinin geçtiğimiz son beş senede devreye girdiği, dijital sağlık hizmetlerinin de bu noktada yeni gelişmekte olduğu göz önünde bulundurulduğunda bu iki konuyu birleştiren çalışmalar çok fazla değildir. Bu noktada üçüncü hedef olan "Sağlıklı ve Kaliteli Yaşam" hedefi ile dijital sağlık hizmetlerini ilişkilendiren çalışmalar bulunmaktadır. Konduri ve diğerleri (2018) Asya ve Afrika'dan seçtikleri beş ülke üzerinde yaptıkları çalışmada daha çok dijital sağlık kayıtlarını incelemişler ve dijital sağlık teknolojilerinin potansiyelini tam 
olarak gerçekleştirmenin bir ön koşulu olarak üçüncü hedefin indikatörlerine/göstergelerine ilişkin ayrıştırılmış verilerin derlenmesini sağlamak için uygun ölçüm çerçeveleri oluşturması gerektiği sonucuna varmışlardir.

Asi ve Williams (2018) ise daha çok kırılgan ülkeler ve savaşın yaşandığı yerlerde sağlık hizmetlerine erişimin zorluğundan bahsettikleri makalesinde Suriye'den bir örnek vermişlerdir. Burada sağllk komplikasyonlarından ölen sivil sayısının savaştan ölenlerden çok daha fazla olduğunu belirtmektedirler. Bunun benzeri pek çok ülke için özellikle üçüncü hedef kapsamında mobil sağlık hizmetlerinin ve tele tıpın çok faydalı olacağını vurgulamaktadırlar. Dijital sağlık araçlarını kullanarak, SDG 3 sonuçlarında sürdürülebilir ilerleme sağlamak için insani çabaların desteklenmesi gerektiği sonucuna varmaktadırlar.

"Telemedicine and e-Health" dergisinin editörleri olan Merrel ve Doarn (2016) senesinde yazdıkları sunuş yazılarında üçüncü sürdürülebilir kalkınma hedefinin doğrudan sağlık hizmetlerini işaret ettiğini, tele tıp ve e-sağlık uygulamalarının da bu hedefe katkı sağlayan unsurlar olduğunu belirtmektedirler.

Palozzi, Schettini ve Chirico (2020) tele tıp uygulamaları ile sağlık hizmetlerine erişimi sürdürülebilir kalkınma hedefleri ile geliştirmeyi irdelediklerinde çalışmalarında tele tıp uygulamalarının geleneksel bakıma göre en büyük avantajlarından birinin, belirli bir düzeyde tecrit halinde yaşayan bir nüfus için tıbbi bakıma erişimin artması potansiyelini sağladığını belirtmektedirler. Üçüncü ve onuncu sürdürülebilir kalkınma hedeflerinden yola çıkan Palozzi ve diğerleri (2020) yaptıkları teorik çalışmada bu hedeflerle tutarlı bir şekilde sağlık sistemi sürdürülebilirliği için itici güç olarak yeni dijital teknolojilerin kullanılmasıyla ilgili sağlık politikası tartışmalarını teşvik etmeyi amaçlamışlardır.

Alverson (2021) ise teorik çalışmasında tele sağlık uygulamalarının üçüncü, dördüncü ve on yedinci sürdürülebilir kalkınma hedefleri ile ilişkili olduğunu iddia etmektedir. Tele sağlığın bir etkisinin olması için, temiz suya erişim, yeterli beslenme, atık yönetimi, elektriğe erişim ve internet gibi diğer konuların da ele alınması gerektiğini belirtmektedir.

Alam, Hu ve Barua (2018) yüksek internet penetrasyonuna sahip Dhaka'da mobil sağlik hizmetleri sunan hastanelerde bu hizmetlerden faydalanan kişiler üzerinde bir çalışma gerçekleştirmişlerdir. Halkın bu 
hizmetlere adaptasyonunu etkileyen faktörleri belirleyerek bu faktörler 1şı̆̆ında mobil sağlık ve tele tıp hizmetlerinin geliştirilmesine sürdürülebilir kalkınma hedefleri kapsamında katkı sunmuşlardır.

Şimdiye kadar verilen bilgiler ışı̆̆ında da bu çalışmada sürdürülebilir kalkınma hedeflerinden özellikle Hedef 3, Hedef 10 ve Hedef 13'ün dijital sağlık hizmetleri ile ilişkilendirilebileceği düşünülmektedir. Burada üçüncü hedef olan "Sağlıklı ve Kaliteli Yaşam” ile sağlıklı yaşamlar sağlanmaya ve her yaştaki insanlar için refah teşvik edilmeye çalışılmaktadır. Onuncu hedef olan eşitsizliklerin azaltılması ile ülke içi ve ülkeler arasında eşitsizliklerin azaltılması hususu vurgulanmaktadır. On üçüncü hedef olan "İklim Eylemi" ile de iklim değişikliği ve etkileriyle mücadele için acil önlemler alınmaya çalışılmaktadır.

Sağlıklı ve kaliteli yaşamı her yaşta güvence altına almak amacıyla oluşturulan Hedef 3'ün, alt maddelerine de bakıldığında aslında sağlık alanı ile ilgili bir hedef olduğu görülmektedir, bu hedefi dijital sağlık hizmetleri ile birlikte de değerlendirmenin de uygun olacağı düşünülmektedir. Çünkü, dijital sağlık hizmetleri kendi içerisinde değerlendirildiğinde, yukarıda da bahsedilen pek çok makalede belirtildiği gibi bu hedefe doğrudan katkı sunmaktadır. Özellikle mobil sağlık ve tele tıp uygulamaları ile kişiler yerden ve zamandan bağımsız olarak sağlık hizmetlerine kolayca erişim imkânı yakalamaktadırlar. Günümüz şartları düşünüldüğ̈ünde ise bulaş riskinin dışarıda daha fazla olması sebebiyle evlerde kalınmasına da katkı sunacak, COVID-19 gibi ileride oluşma ihtimali olan salgınlar için de oldukça güzel bir alternatif yöntem haline geleceği düşünülmektedir.

Asıl önemli husus, bu hizmetleri her yaştan ve de her gelir düzeyinden insanlar için ulaşılabilir hale getirmektir. Bölüm 3.1'de bu konuda ülkemizde uygulamalar göz önünde bulundurulduğunda daha çok özel hastaneler, özel sigorta şirketleri bu hizmetleri hastalarına sağlamaktadırlar. Oysa ülkemizde devlet hastanelerinin sayısı özel hastanelerden daha fazla iken, genel sağlık sigortası harcamaları kapsamında da yine devlet hastanesi ödemeleri özel hastanelerden daha fazladır (Yıldırım ve Konca, 2018), yani bireyler de özel hastanelerden ziyade devlet hastanelerini tercih etmektedirler. Dolayısıyla dijital sağlık hizmetleri kapsamında mobil sağlık ve tele tıp uygulamalarının daha ulaşılabilir hale getirilmesi sağlanmalıdır, böyle bir durum sürdürülebilir kalkınma he- 
defleri kapsamında da üçüncü hedefe doğrudan katkı sağlayacaktır. Burada Dünya Sağlık Örgütü'nün de sayfasında yer alan bir ifadeyi hatırlatmakta fayda görülmektedir, ifadede dijital sağlık hizmetlerinin Hedef 3'e ulaşma konusundaki ilerlemeyi hızlandırmak için fırsatlar sunduğu belirtilmiştir (WHOb, t.y.).

Ülke içi ve ülkeler arası eşitsizliklerin azaltılmasına odaklanan Hedef 10 'a da dijital sağlı hizmetleri vasıtası ile katkı sunulabileceği düşünülmektedir. Özellikle alt maddelerde de vurgulanan "yaş, cinsiyet, engellilik, ırk, etnik köken, din, ekonomik ya da başka bir durumuna bakılmaksızın herkesin sosyal, ekonomik ve siyasi olarak kapsanmasını sağlamak ve güçlendirmek" ve "en az gelişmiş ülkeler, Afrika ülkeleri, gelişmekte olan küçük ada devletleri ve karayla çevrili gelişmekte olan ülkeler olmak üzere ihtiyacın en fazla olduğu ülkelere, ulusal plan ve programlarına uyumlu olacak şekilde, doğrudan yabancı yatırımları da kapsayan nakit akışlarını ve resmi kalkınma yardımlarını teşvik etmek" kapsamlarında ele alındığında dijital sağlık hizmetlerinin bu hususlara ciddi manada katkısı olacağı düşünülmektedir.

3. Hedef için de bahsedilen durumlar burası için de geçerlidir, çünkü ülke içi sosyo ekonomik durum göz önünde bulundurulduğunda bile belirtilen dijital sağlık hizmetleri herkes için ulaşılabilir değildir, dolayısıyla ülke içi sosyal ve ekonomik olarak kapsandığında herkes ülkenin refahını artıracak hizmetlerden olan dijital sağlık hizmetlerine daha kolay ulaşabilecektir. Ayrıca, ülkeler arası durum düşünülürse, pek çok az gelişmiş ülkede sağlık personeli sıkıntısı olduğu aşikardır. Yine dijital sağlık hizmetleri ile bu ülkelere sağlık hizmeti sunularak onların da kalkınmasına katkı sunulacağı düşünülmektedir.

Diğer bir sürdürülebilir kalkınma hedefi olan Hedef 13 ise "İklim Eylemi" başlığıyla ele alınan iklim değişikliği ve etkileriyle mücadele için acil önlem almaya çalışmaktadır. İlk başta düşünüldüğü zaman bu hedef ile doğrudan bir bağlantı kurulamayabilir. Oysa, dijital sağlık hizmetlerinin de bu amaca ulaşılmasında olumlu bir katkısı vardır. Daha fazla insan dijital sağlık hizmetlerini kullanmaya alıştıkça, daha az hastane ziyareti ve daha fazla elektronik sağlık kaydı yer alacaktır. Öte yandan hastane ve doktor ziyaretlerinin azalması ile birlikte daha az karbon emisyonu oluşmasından dolaylı da olsa bir katkı sunulmuş olacaktır. 
Bunun yanında hastaneye gidildiğinde olası kâğıt kullanımı ya da sarf malzemeleri de yine dolaylı yoldan azalmış olacaktır.

Son olarak Türkiye'de dijital sağlık hizmetleri hakkında bir hususun da hatırlatılmasında fayda vardır. Doğramacı'nın İstanbul Hukuk Mecmuası'nda 2020'de yayınlanan makalesinde belirtildiği üzere "Ülkemizde, çok yakın zamana kadar, hekim ile hastanın fiziki olarak temas kurması gerektiği ve bu doğrultuda uzaktan teşhis ve tedavinin, dolayısıyla tele tıp uygulamalarının, yasak ve hatta suç olduğu kabul edilmekteydi." Dolayısıyla Türkiye'de dijital sağlık hizmetlerinin gelişmesindeki en büyük engellerden biri de bu durum olarak ortaya çıkmaktadır. Yasal durum hala değişiklik göstermese de özellikle COVID-19 salgınının da etkisiyle kendiliğinden girilen bir süreç olduğu aşikardır. Dolayısıyla bu tür yasal düzenlemelerin de sürdürülebilir kalkınma hedeflerine ciddi katkı sağlayacak dijital sağlık hizmetlerinin daha yaygın hale getirilmesi amacıyla yeniden değerlendirilmesi gerektiği düşünülmektedir.

\section{Sonuç ve Değerlendirme}

Günümüzde insanların pek çoğu, sorunlarını dijital teknolojileri kullanarak çözmeyi tercih etmektedirler. Sağlık problemleri de bunlardan bir tanesidir. Sağlık alanında alınan hizmetlerin dijital teknolojilerin etkisiyle ciddi bir dönüşüm yaşadığını, tüm dünyada olduğu gibi Türkiye'de de görülmektedir. Bu yeni teknolojiler sayesinde insanlar sağlık hizmetlerine çok daha kolay erişim sağlayabilmektedirler. Üstelik yüz yüze herhangi bir sağlık kuruluşuna gitmek durumunda kalmadan pek çok konuda işlerini hızlı ve kolay bir şekilde çözüme ulaştırabilmektedirler.

Neredeyse her şeyin online hizmetlere bağlandığı COVID-19 ile birlikte sağlık hizmetlerinde dijitalleşmeye olan ihtiyaç daha da önemli hale gelmiştir. Türkiye de dünyada hızla yükselen dijital sağlık hizmetleri trendine COVID-19'un da büyük etkisiyle daha hızlı uyum sağlama sürecine girmiş bulunmaktadır. Dolayısıyla tüm dünyayı kötü bir şekilde etkisine alan COVID-19 dijital sağlık hizmetlerinin önemini daha fazla kanıtlamış ve dijitalleşmeyi de tetiklemiş durumdadır.

Ülkemiz sağlıkta pek çok faktör itibariyle dijitalleşme sürecine girmiş ve ciddi gelişmeler kat etmiştir. E-devlet üzerinden entegrasyon sağlanan MHRS sistemi ile vatandaşlar hastaneye gitmeden randevularını 
alabilmekte, e-nabızdan tahlil sonuçlarını ve raporlarını görebilmektedirler, devlet tarafından sunulan sağlık hizmetleri daha teknoloji temelli bir hale gelmeye başlamıştır. Bu uygulamalar benzeri, özellikle hastanelerin dijitalleşmesini sağlayacak, doktorların hastaları hakkında geçmiş verilerine kolaylıkla ulaşmalarına imkân verecek online sistemler geliştirilmeye de devam etmektedir. Ancak, hastaların hastane ortamına gitmeden doktorları ile yüz yüze iletişim kurmalarını sağlayacak tele tıp ve mobil sağlık uygulamaları henüz istenilen düzeye gelememiştir. Ayrıca, bu tarz uygulamaları hayata geçiren hastaneler özelinde değerlendirildiğinde de bu hizmetler toplumun büyük bir kesimi için ulaşılabilir durumda değildir.

Bu açılardan bakıldığında sürdürülebilir kalkınma hedefleri ve sağlık ilişkisi karşımıza çıkmaktadır. Çünkü, "küresel yoksulluğu sona erdirmek, herkes için haysiyetli bir yaşam inşa etmek ve kimseyi geride b1rakmamak için bir yol haritası" olarak tanımlanan bu hedefler arasında dijital sağlık hizmetleriyle doğrudan ya da dolaylı olarak bağlantı kurulabilecek ve bu hedeflere ulaşılmasına katkı sağlayacak gelişmeler sağlanabilecektir.

Çalışma bu bakış açısıyla yola çıkmış, dijital sağlık hizmetlerinin kapsamını, Türkiye'de dijital sağlık hizmetlerini özetlemiş, sonrasında sürdürülebilirlik kavramı ile sürdürülebilir kalkınma hedefleri anlatılmıştır. Son olarak çalışmanın esas çıkış noktası olan dijital sağlık hizmetlerinin sürdürülebilir kalkınma hedeflerine olası katkıları açıklanmıştır. Konu, bu hedeflerin 2015 Eylül itibariyle konulması sebebiyle yeni sayılabilecek bir konudur, ayrıca dijital sağlık hizmetleri ile de bağdaştıran çok fazla çalışma bulunmamaktadır. Literatürde bu konuda yapılmış çalışmalardan bazılarına da belirtilen bölümde yer verilmiştir. Sürdürülebilir kalkınma hedeflerinden 3, 10 ve 13. Hedefler özellikle ele alınmıştır.

Dünya Sağlık Örgütü'nün 2020-2025 “Dijital Sağlıkta Küresel Strateji” raporu da sürdürülebilir kalkınma hedefleri ile dijital sağlık hizmetleri arasında ilişkileri destekleyici nitelikte maddeler içermektedir. Buna göre, global strateji özellikle birey merkezli dijital sağlık çözümleri geliştirilmesi ve benimsenmesini hızlandırıp herkes için sağlığ1 iyileştirme vurgusu yapmıştır. Bu şekilde sürdürülebilir kalkınma hedeflerine ulaşmanın kolaylaşacağını belirtmektedir. Ayrıca dijital sağlık hizmetlerine erişimin artırılması manasında da üye ülkelerin birbirlerini destek- 
lemesi gerektiğini de vurgulamaktadırlar. Raporda bahsedilen hususlar da aslında sürdürülebilir kalkınma hedeflerinden üçüncü ve onuncu hedefi işaret etmektedir.

Mobil aplikasyonlar, uzaktan hasta izleme cihazları ve sensörler gibi bilgi iletişim teknolojileri-BİT (ICT-Information Communication Technology) olarak tabir edilen teknolojilerin sağlık sistemine entegre edilmesi sayesinde sağlık hizmetlerine olan erişim genişletilebilir ve sağlık hizmeti maliyetleri düşürülebilir. Ancak, bakıldığında birçok ülke geniş ölçekte sürdürülebilir dijital sağlık çözümlerinin uygulanmasında birtakım zorluklarla karşılaşmaktadır (https://www.digitalhealthindex.org/). Türkiye'de de bu açıdan değerlendirildiğinde sağlıkta dijitalleşme kapsamında daha önceki başlıklarda da detaylı bir şekilde değinildiği üzere çok büyük gelişmeler kat edilmiştir. Ancak, mobil sağlık hizmetleri ve tele tıp manasında henüz alışma sürecinde olduğumuzu söylenebilir.

Ülkemizin tele tıp ve mobil sağlık hizmetleri kapsamında sürdürülebilir kalkınma hedeflerine destek olmak amaciyla bu hizmetlerin vatandaşlar tarafından daha ulaşılabilir hale getirilmesi ve yaygınlaştırılması noktasında adımlar atması önemlidir. Yaygın hale getirilen bu hizmetlerle hem sağlık çalışanlarının iş yüklerinin hafifletilmesi sağlanabilecekken, hastanelerdeki yoğunluğun azaltılması özellikle de salgın koşullarında büyük faydalar getirecektir. Bunun yanında, daha ileride Türk doktorların yine bu teknolojiler vasıtasıyla az gelişmiş ülkelerde sağlık hizmetleri ihtiyaçları olan kişilere de ulaşması sağlanabilir. Dolayısıyla sırf bu uygulamaların hayata geçirilmesi ile üçüncü, onuncu ve on üçüncü hedeflere katkı sağlanmış olacaktır.

Gerçekleşen duruma bakıldığında, bahsedilen dijital sağlık hizmetlerinin özel hastaneler ve özel sigorta kuruluşlarının müşterileri için şu anda daha çok devrede olduğunu görmekteyiz. Bazı hastaneler anlaşmalı oldukları laboratuvarlar sayesinde mobil görüşme sonrasında tahlil gerektiğinde anlaşmalı laboratuvarlarını hastaya yönlendirerek evde kan alınmasını da sağlamaktalar. Ancak, bu hizmetlerin ortalama gelir düzeyindeki bir vatandaşın erişmesinin oldukça zor olduğu hizmetler olduğu düşünülmektedir. Dolayısıyla, uygulamaların devlet hastanelerini de kapsayacak şekilde yaygınlaştırılması için devletin de dijitalleşme kapsamında adımlar atması önemli görülmektedir. 
Bu konuda Akdeniz Üniversitesi Rektörü Prof. Dr. Özlenen Özkan Şubat 2021 tarihinde gerçekleştirdiği bir açıklamasında kanser hastalarında kanseri tanısı, tedavisi ve de takiplerinde COVID-19 sebebiyle gecikmeler olduğunu belirtmiştir (Akdeniz'den, 2021). Aynı durum pek çok hastalık için de geçerlidir. Elbette dijital sağlık uygulamaları ile özellikle kanser gibi ciddi hastalıklarda teşhis koymak zor olsa da bazı ön belirtiler için bu hizmetlerin kullanılması hayat kurtarıcı nitelikte olabilmektedir. Türk Tabipleri Birliği Etik Kurulu da Ocak 2021'de tele tıp uygulamaları özelinde bir açıklama yapmıştır. Onlar da açıklamalarında tele tıp uygulamalarının tamamen geleneksel yüz yüze hasta doktor ilişkisinin yerine geçemese de tıbbi yardıma erişim noktasında sıkıntılar yaşanması halinde bireylere katkılar sunacağını belirtmişlerdir (Türk Tabipleri Birliği, 2021).

Dijital sağlık hizmetlerinin günümüzdeki sağlık sistemine olan katkısı aynı zamanda da sürdürülebilir kalkınma hedeflerine olan katkısı, çalışmamızda, halihazırdaki uygulamalar ve geçmiş çalışmalar çerçevesinde derlenerek ele alınmaya çalışılmıştır. Konu hakkında ileride yapılacak çalışmalar tele tıp ve mobil sağlık uygulamalarının neticesini ölçmeye yönelik olabilir. Çünkü, halihazırda bu uygulamalarla alakalı özel hastanelerin bazılarının da geliştirdiği aplikasyonlarda çalışmada özellikle üzerinde durulan canlı görüşme hizmet desteklenmemektedir. Dolay1sıyla indirme sayıları bir parametre olabilecekken burada böyle bir değerlendirme fırsatı da kalmamaktadır. Bu durumda Türkiye'de kullanılan bu dijital sağlık hizmetlerinin sonuçları ve yaygınlığı hakkında bir çalışma yapılması faydalı olacaktır. Sürdürülebilir kalkınma hedefleri kapsamında da bu hizmetleri kullanan hastanelerle de görüşülerek daha fazla nasıl yaygın hale getirilebileceği konusunda çalışmalar yapılması uygun olacaktır. 


\title{
EXTENDED ABSTRACT
}

\section{Evaluation of Digital Health Services in Terms of Sustainable Development Goals}

\author{
Hilal Özen \\ Trakya University
}

Today, the effect of digitalization is felt in every industry. Since digital technologies help people to ease their lives and solve their problems quickly, people are becoming more engaged to these technologies. Especially the spread of ICT technologies has changed the application of many traditional services. Health industry is also one of the most affected area from digital technologies. In Turkey health industry has undergone a serious transformation with this effect. Thanks to these new technologies, people can access to health services much more easily. Moreover, they can solve their problems quickly and easily without the need of a physical visit to a hospital or clinic.

The effect of digital technologies was duplicated with different environmental factors. The most important one is of course COVID-19 pandemic. With COVID-19 the need for digitalization in healthcare has become much more important. Turkey has also entered the process of adapting to the rapidly rising digital health services trend in the world, with the great effect of COVID-19. Therefore, COVID-19, which has badly affected the whole world, has further proven the importance of digital health services and has triggered digitalization.

Turkey has entered to digitalization process in healthcare before this unexpected process, but especially in telemedicine and mobile health technologies the process accelerated after COVID-19. Since people were hesitating to go even for their routine inspections, these new technologies were a good solution for them. In the regular digitalization process, Turkish hospitals, both public and private have entered to an integrated system where the doctors are able to reach the results of the patients' analysis and reports via e-government citizen service applications. Also similar to these applications, online systems continue to be developed 
that will enable the digitalization of hospitals and allow doctors to easily access historical data about their patients.

However, in Turkey, telemedicine and mobile health applications that will enable patients to communicate with their doctors without going to the hospital or clinic have not reached the desired level yet. In addition, these services are unfortunately not accessible to a large part of the society. Since only some of the private hospitals are giving the opportunity for using telehealth and mobile health applications to their patients.

From this viewpoint the importance of the relationship between sustainable development goals and healthcare emerges. Because, these goals, which are defined as "a roadmap to end global poverty, build a dignified life for everyone and leave no one behind", can be directly or indirectly linked with digital health services, and developments in healthcare services will contribute to the achievement of these goals. In this respect this study focuses on a new subject, since sustainable development goals were set in September 2015, and there are not many studies that relate it to digital health services. Third, tenth and thirteenth Sustainable Development Goals were particularly addressed.

It is important for Turkey to take steps to make digital health services more accessible and widespread for citizens in order to support sustainable development goals within the scope of telemedicine and mobile health services. With these services, both the workload of health workers can be alleviated, and the reduction of the density in hospitals will bring great benefits, especially in pandemic conditions. Besides, in the future, Turkish doctors can also be provided with these technologies to reach people in need of health services in underdeveloped countries. Therefore, the implementation of these practices will contribute to the third, tenth and thirteenth goals.

When the implementations and the actual situation is considered, it could be seen that digital health services are currently more accessible for patients of private hospitals and private insurance companies. Some hospitals also ensure the application of blood tests at home by directing their contracted laboratories to the patient when analysis is required after mobile calls. However, the access to these services is considered to be very difficult for a citizen with an average income level. Therefore, it is important for the government to take steps within the scope of digital- 
ization in order to expand the applications to also include the public hospitals.

The contribution of digital health services to the current health system, as well as to the sustainable development goals was discussed in this study by compiling it within the framework of current practices and past studies. Future studies on the subject may focus on measuring the results of telemedicine and mobile health applications. Because, the live call service, which is especially emphasized in the study, is not supported in current applications. Therefore, while the number of downloads can be a parameter, there is no opportunity for such an evaluation. In this case, it would be beneficial to conduct a study on the results and prevalence of these digital health services used in Turkey. Within the scope of sustainable development goals, it would be appropriate to discuss with the hospitals using these services and to work on how the use of these applications could be broadened.

\section{Kaynakça / References}

Acıbadem evinizde, (t.y.). 5 Nisan 2021 tarihinde https://www.acibadem.com.tr/acibadem-evinizde/ adresinden erişildi.

Ada sigorta canlı ve görüntülü sağlık danışmanlığı hizmeti, 5 Nisan 2021 tarihinde https://www.adasigorta.com.tr/sayfa-canli-ve-goruntulusaglik-danismanligi-hizmeti-8 adresinden erişildi.

Ak, B. (2013). Sağlıkta yeni hedef: Dijital hastaneler. Akademik Bilişim 2013 XV. Akademik Bilişim Konferansı Bildirileri. 23-25 Ocak 2013 - Akdeniz Üniversitesi, Antalya, 971-976.

Akdağ, R. (2012). Türkiye sağlıkta dönüşüm programı, değerlendirme raporu (2003-2011), 1 Nisan $2021 \quad$ tarihinde https://sbu.saglik.gov.tr/Ekutuphane/kitaplar/SDPturk.pdf adresinden erişildi.

Akdeniz'den, e-dergi (Ocak-Şubat 2021). Kanser Tedavisinde Son Teknoloji Akdeniz Üniversitesi'nde. 15 Nisan 2021 tarihinde http://galeri.akdeniz.edu.tr/Akdenizden/pdf/e-Akdenizden-03.pdf adresinden erişildi. 
Alam, M. Z., Hu, W. ve Barua, Z. (2018). Using the UTAUT model to determine factors affecting acceptance and use of mobile health (mHealth) Services in Bangladesh. Journal of Studies in Social Sciences, 17(2), 137-172.

Alverson, D. C. (2021). International and global telemedicine: Making It Work. Telemedicine, Telehealth and Telepresence içinde (s.235-255). Springer Nature Switzerland AG 2021235 R. Latif et al. (eds.). https://doi.org/10.1007/978-3-030-56917-4 15.

Anadolu Sigorta 7/24 Sağlık Danışmanlığı, (2020, Mart 24). 5 Nisan 2021 tarihinde https://www.anadolusigorta.com.tr/medyada-biz/basinbultenleri/anadolu-sigortadan-7-24-canli-ve-goruntulu-saglikdanismanligi-hizmeti adresinden erişildi.

Asi, Y. M., and Williams, C. (2018). The role of digital health in making progress toward Sustainable Development Goal (SDG) 3 in conflictaffected populations. International Journal of Medical Informatics, 114, 114-120, http://dx.doi.org/10.1016/j.jimedinf.2017.11.003.

Bektaş, G. ve Şimşek, F. (2016). İleri yaş sağlık turizminde mobil sağlık hizmetlerinin önemi. Sağlık Akademisyenleri Dergisi, 3(4), 179-185.

BM - Birleşmiş Milletler, Ekonomik ve Sosyal İşler Dairesi, (t.y.). 17 Hedef Tarihi, 20 Mart 2021 tarihinde https://sdgs.un.org/goals adresinden erişildi.

CCR Easy Connetct Video, (2019). 5 Nisan 2021 tarihinde https://www.ccr.group/easyconnect-video/ adresinden erişildi.

Deloitte, 2021 Global Healthcare Outlook: Accelerating Industry Change, 5 Nisan 2021 tarihinde https://www2.deloitte.com/global/en/pages/life-sciences-andhealthcare/articles/global-health-care-sector-outlook.html adresinden erişildi.

Denizli Özel Sağlık Hastanesi, Sağlık Evde (t.y.). 5 Nisan 2021 tarihinde https://www.saglikhastanesi.com.tr/saglik-evinizde/ adresinden erişildi.

Dijital Hastane, (2015, 2 Eylül). HBYS (Hastane Bilgi Yönetim Sistemi), 5 Nisan 2021 tarihinde https://dijitalhastane.saglik.gov.tr/TR,4881/hbys-hastane-bilgiyonetim-sistemi.html adresinden erişildi.

Doctor Turkey, (2020). 5 Nisan 2021 tarihinde https://www.doctorturkey.com.tr/ adresinden erişildi. 
Doğramacı, Y. G. (2020). Teletıp, Sağlık Turizmi ve Uzaktan Sağlık Hizmetleri: Mesafeli Sözleşmeler. İstanbul Hukuk Mecmuası, 78(2), 657-710. DOI: 10.26650/mecmua.2020.78.2.0014.

Dünya Gazetesi (2018, 1 Aralık). E-sağlık sektöründeki büyüme ivme kazand1. 5 Nisan 2021 tarihinde https://www.dunya.com/saglik/esaglik-sektorundeki-buyume-ivme-kazandi-haberi-433626 adresinden erişildi.

Faggini, M., Cosimato, S., Nota, F. D., and Nota, G. (2018). Pursuing Sustainability for Healthcare through Digital Platforms. Sustainability, 11, 1-15, doi:10.3390/su11010165.

Florence Online Tibbi Danışma Hizmeti, (2020). 5 Nisan 2021 tarihinde https://online.florence.com.tr/ adresinden erişildi.

Frank, S. R. (2000). Digital health care-the convergence of health care and the Internet. Journal of Ambulatory Care Management, 23(2) 8-17.

Gromenko, A. (2021). 7 points checklist for mobile health app development, 19 Nisan 2021 tarihinde https://code-care.com/blog/healthcaremobile-application-development/ adresinden erişildi.

Hizmet Hastanesi e-Doktor, (t.y.). 5 Nisan 2021 tarihinde https://www.hizmethastanesi.com/kampanyalar/hizmet-hastanesi-edoktor/ adresinden erişildi.

İş Dünyası ve Sürdürülebilir Kalkınma Derneği (SKD Türkiye), (2016). 100 Maddede Sürdürülebilirlik Rehberi, 5 Nisan 2021 tarihinde http://www.skdturkiye.org/files/yayin/100-maddedesurdurulebilirlik-rehberi.pdf adresinden erişildi.

Kent Online Doktor, (t.y.). 5 Nisan 2021 tarihinde https://www.kentsaglikgrubu.com/online-doktor.html adresinden erişildi.

Khilnani, A., Schulz, J., and Robinson, L. (2020). The COVID-19 pandemic: new concerns and connections between eHealth and digital inequalities. Journal of Information, Communication and Ethics in Society, 18(3) 393-403, DOI 10.1108/JICES-04-2020-0052.

Kılınç Hukuk ve Danışma, (2020). Türkiye'de Sağlık Hizmetlerinin Dijitalleşmesi. $\quad 5 \quad$ Nisan 2021 tarihinde https://www.kilinclaw.com.tr/turkiyede-saglik-hizmetlerinindijitallesmesi/ adresinden erişildi. 
Konduri, N., Aboagye-Nyame, F., Mabirizi, D., Hoppenworth, K., Kibria, M. G., Doumbia, S., Williams, L. ve Mazibuko, G. (2018). Digital health technologies to support access to medicines and pharmaceutical services in the achievement of sustainable development goals. Digital Health, 4, 1-26, DOI: 10.1177/2055207618771407.

Kosif, K. F. (2019). Kurumlarm Dijital Dönüşüm Süreçlerinin İncelenmesi: Bir Sağllk Kurumu İçin Öneri. (Yayınlanmamış Yüksek Lisans Tezi). İstanbul Üniversitesi Fen Bilimleri Enstitüsü Enformatik ABD, İstanbul.

Kuter, N. ve Ünal, H. E. (2009). Sürdürülebilirlik Kapsaminda Ekoturizmin Çevresel, Ekonomik ve Sosyo-Kültürel Etkileri. Kastamonu Üniversitesi Orman Fakültesi Dergisi, 9( 2), 146-156.

Mathews, S. C., McShea, M, Hanley, C. L., Ravitz, A., Labrique, A. B. ve Cohen, A. B. (2019). Digital health: a path to validation. NPJ Digital Medicine, 2, 1-9, https://doi.org/10.1038/s41746-019-0111-3.

Medical Park Evde, (2020, May1s 6). 5 Nisan 2021 tarihinde https://www.medicalpark.com.tr/online-doktor-gorusmesi/n-230 adresinden erişildi.

Medicana Online Hekim, (t.y.). 5 Nisan 2021 tarihinde https://www.medicana.com.tr/ OnlineHekim adresinden erişildi.

Memorial E-Doktor (t.y.). 5 Nisan 2021 tarihinde https://www.memorial.com.tr/memorial-evinizde adresinden erişildi.

Merrell, R. C., ve Doarn, C. R. (2016). Sustainable Development Goals and Telemedicine. Telemedicine and E-health, 22, 10, DOI: 10.1089/tmj.2016.29013.rcm.

Miaclinics E-Doktor - Online Doktor, (t.y.). 5 Nisan 2021 tarihinde https://miaclinics.com/e-doktor-ve-goruntulu-doktor-gorusmesi/ adresinden erişildi.

Mburu, S. N., and Kamau, O. (2018). Framework for Development and Implementation of Digital Health Policies to Accelerate the Attainment of Sustainable Development Goals: Case of Kenya eHealth Policy. 11th Health Informatics in Africa Conference (HELINA 2018), 32-38.

Novillo-Ortiz, D, Marin, H. D. F., Saigí-Rubió, F. (2018). The role of digital health in supporting the achievement of the Sustainable Development Goals (SDGs). International Journal of Medical Informatics, 114, 106-107, https://doi.org/10.1016/j.ijmedinf.2018.03.011. 
Özge, A. ve Uludüz, D. (2020). Pandemi Döneminde Öne Çıkan Bir Gerçek: Teletıp Uygulamaları. Nörolojik Bilimler ve COVID-19 içinde (s.79-85). 1. Baskı. Ankara: Türkiye Klinikleri.

Palozzi, G., Schettini, I. ve Chirico, A. (2020). Enhancing the Sustainable Goal of Access to Healthcare: Findings from a Literature Review on Telemedicine Employment in Rural Areas. Sustainability, 12, 3318; doi:10.3390/su12083318.

Peker, S. V, Giersbergen M. Y. V. ve Biçersoy, G. (2018). Sağlık bilişimi ve Türkiye'de hastanelerin dijitalleşmesi. Sağllk Akademisi Kastamonu, 3(3), 228-267.

Presti, L. L., Testa, M., Marino, V., ve Singer, P. (2019). Engagement in healthcare systems: Adopting digital tools for a sustainable approach. Sustainability, 11, 1-15; doi:10.3390/su11010220.

Sherman, J. D., Thiel, C., MacNeill, A., Eckelman, M. J., Dubrow, R., Hopf, H. Lagasse, R., Bialowitz, J.Costello, A., Forbes, McG., Stancliffe, R., Anastas, P., Anderko, L., Baratz, M., Barna, S., Bhatnagar, U., Burnham, J. Cair, Y. ve Bilec, M. M. (2020). The green print: Advancement of environmental sustainability in healthcare. Resources, Conservation and Recycling, 161, 1-11. https://doi.org/10.1016/j.resconrec.2020.104882

Statista, (2021). 2015 ilk çeyreğinden 2020 son çeyreğine kadar Google Play'de bulunan mobil sağlık aplikasyon sayısı. 5 Nisan 2021 tarihinde https://www.statista.com/statistics/779919/health-appsavailable-google-play-worldwide/ adresinden erişildi.

T.C. Cumhurbaşkanlığı Yönetim Hizmetleri Genel Müdürlüğü, Bilgi ve Belge Yönetimi Dairesi Başkanlığı, (2020). Sürdürülebilir Kalkınma Amaçları Değerlendirme Raporu, ISBN NO : 978-605-7751-13-3, Ankara.

T.C. Cumhurbaşkanlığı Strateji ve Bütçe Başkanlığı, (t.y.). Sürdürülebilir Kalkınma Hakkında Temel Bilgiler. 5 Nisan 2021 tarihinde http://www.surdurulebilirkalkinma.gov.tr/temel-tanimlar/ adresinden erişildi.

Telemedico, (t.y.). 5 Nisan 2021 tarihinde https://telemedi.co/tr/ adresinden erişildi.

Tezcan, C. (2016). Sağlığa yenilikçi bir bakış açısı: Mobil sağlık. TÜSİADT/2016-03/575. $\quad 5 \quad$ Nisan 2021 tarihinde https://tusiad.org/tr/yayinlar/raporlar/item/8676-dunya-ornekleriisiginda-turkiyede-mobil-saglik adresinden erişildi. 
Tongue, B. (2019). Designing sustainability into the Digital Healthcare Revolution. British Journal of Healthcare Management, 25(4), 1-3. https://doi.org/10.12968/bjhc.2019.0038.

TÜIKK, Hanehalkı Bilişim Teknolojileri (BT) Kullanım Araştırması, 2020, Sa-

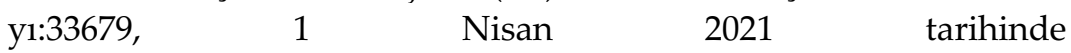
https://data.tuik.gov.tr/Bulten/Index?p=Hanehalki-BilisimTeknolojileri-(BT)-Kullanim-Arastirmasi-2020-33679 adresinden erişildi.

Türk Tabipleri Birliği (TTB), (2021). 1 Nisan 2021 tarihinde https://www.ttb.org.tr/userfiles/files/teletip_hakkinda_gorus.pdf adresinden erişildi.

UN Sustainable Development Summit 2015, Press Release (BM Sürdürülebilir Kalkınma Zirvesi 2015, Basın Bülteni) 15 Mart 2021 tarihinde https://sustainabledevelopment.un.org/content/documents/8331Curt ain\%20raiser\%20PR_Sustainable\%20Development\%20Summit.pdf adresinden erişildi.

Ylldız, H. (2016). Innovative practices in the healthcare industry within the context of sustainability: Green hospitals. Kafkas Üniversitesi İktisadi ve İdari Bilimler Fakültesi KAÜIİBFD, 7, 13, 323-340.

Yıldırım, H. H., ve Konca, M. (2018). Türkiye'de özel sağlık kurumları sektörü: mevcut durum, sorunlar ve çözüm öneriler. TÜSPE-Türkiye Sağlık Politikaları Enstitüsü, TÜSPE Yayınları, Göktuğ Ofset, Ankara.

Weinstein, R. S., Lopez, A. M., Joseph, B. A., Erps, K. A., Holcomb, M., Barker, G. P., Krupinski, E. A. (2014). Telemedicine, telehealth, and mobile health applications that work: Opportunities and barriers. The American Journal of Medicine, 127(3), 183-187.

Wernhart, A., Gahbauer, S. ve Haluza, D. (2019). eHealth and telemedicine: practices and beliefs among healthcare professionals and medical students at a medical university. Plos One, 14(2)xx-xx, https://doi.org/10.1371/journal.pone.0213067.

WHO, World Health Organization-a (2010). Telemedicine: Opportunities and developments in Member States. Report on the second global survey on eHealth Global Observatory for eHealth series - Volume 2. 2 Nisan 2021

tarihinde https://www.who.int/goe/publications/goe_telemedicine_2010.pdf adresinden erişildi. 
WHO, World Health Organization-b (t.y.). Digital health-overview. 23 Mart 2021 tarihinde https:/www.who.int/health-topics/digitalhealth\#tab=tab_1 adresinden erişildi.

World commission on environment and development (WCED) (1987). Our Common Future: Report of the World Commission on Environment and Development. Oxford: Oxford University Press.

\section{Kaynakça Bilgisi / Citation Information}

Özen, H. (2021). Dünya sağlık hizmetlerinin sürdürülebilir kalkınma hedefleri açısından değerlendirilmesi. OPUS-Uluslararası Toplum Araştırmaları Dergisi, 17(38), 5440-5472. DOI: 10.26466/opus.927187 